\title{
Buddhist Nuns in Early Medieval Japanese Sources (In Comparison With Tibetan Yoginis and Chinese Nuns)
}

\author{
Elena Sergeevna Lepekhova \\ Institute of Oriental Studies, Russian Academy of Sciences, Moscow, Russia
}

\begin{abstract}
A history of the formation of the first Buddhist Sangha in Japan in VI c. A.D. could serve as an example of the unique history of interaction between Buddhism and Japanese autochthonous religion Shinto. The first Buddhist Sangha in Japan, at the same time was also a female Buddhist community of nuns in this country. It could be assumed that the choice of the women, designed to embody the Dharma in Japan, was not accidental and was driven by the perception of the Buddha image at the time of its introduction in Japan in VI century, especially to compare with the hagiographies of Tibetan yoginis (Machig Labdrön, Yeshe Tsogyal) and Chinese nuns ("Bikuni Zhuan") of V-VII cc. With a number of similarities (persecutions of the anti-Buddhists, desire to receive a full knowledge of Dharma), the information of the first Japanese nuns still differ considerably from the hagiographies of yoginis and Chinese Buddhist nuns. The activity of first Japanese nuns, consisted in the worship of the statue of the Buddha, rather remind the shamanistic responsibilities of the Shinto priestesses, who were the intermediates between people and gods. This is reflected in the early Japanese description of Buddhist monks and nuns in Nihon Shōki, Gangoji Garan Engi and Nihon ryōiki as the Shamanistic priests and guardians of the Buddha-image with a special magical status, rather than the preachers of Dharma, in comparison with the Tibetan and Chinese sources.
\end{abstract}

Keywords: Buddhist Sangha, Japanese nuns, Tibetan yoginis, Chinese Buddhist nuns, Machig Labdrön, Yeshe

\section{Introduction}

The introduction of Buddhism to Japan is dated by 552 in Nihon Shōki 日本書紀 “The Annals of Japan”, when the Koreanking Sonmyōn wan 聖明王 (or Seong) of Baekje (Jp.Kudara) 百濟 sent a mission to Japan that included some Buddhist monks, together with an image of Buddha and a number of sutras to introduce Buddhism. As the chronicle reports, the emperor Kimmei 欽明(509-571), after receiving the Korean embassy and accepting the gifts, asked the advice of his three chief counselors: oomi 大臣 (Great Imperial chieftain, or Great Minister) Soga-no Iname 蘇我稲目, ōmuraji (Great Deity chieftain) Mononobe-no Okoshi 物部尾輿 and the other ōmuraji (Great Deity chieftain) Nakatomi no Kamako 中臣鎌子 about the acceptance of a new religion.

While both Mononobe and Nakatomi were against the acceptance of Buddhism, oomi Soga-no Iname supported the new religion. Therefore, an emperor granted to him the stone image of Buddha, and Iname placed it in Owarida palace, later transformed into Buddhist temple (Nihon Shōki, V. II, 1973, pp. 89-90).

Elena Sergeevna Lepekhova, Doctor of Philosophical Sciences, Institute of Oriental Studies, Russian Academy of Sciences.

Correspondence concerning this article should be addressed to 107031, Moscow, Rogdestvenka 12, Institut Vostokovedeniya RAN. E-mail: lenalepekhova@yandex.ru. 
In the temple chronicle “Gangōji Garan Engi Narabi ni Ruki Shizaichō” (元興寺伽藍縁起并流記資財帳, Origins of the Gangōji Monastery and Its Assets), composed in the second half of the 8th century, is given another version about the date 538, which included Empress Suiko 推古 (554-628). It says that the Emperor, on the advice of Minister Soga-no Iname ordered to place a statue of the Buddha in the palace of Suiko in Mukuhara 牟原 (Gangoji garan engi, 1975, p. 85).

Both Nihon Shōki (1973) and Gangoji Engi (1975) agree on one thing: Despite the fact that the so-called "transmission of Buddha's teachings" in Japan had been at the official level, however, Emperor Kimmei at that time did not dare to enter the official cult of the Buddha. Accordingly, because of the uncertain relationship, Kimmei to Buddhism, it's patrons in official sources often are Empress Suiko, or the representatives of Soga clan.

During the reign of emperor Bidatsu 敏達 (572-585), Buddhism continued to invade Japan, while the emperor himself showed no interest in Buddhism, but rather was a follower of Confucianism. Nevertheless, in 577, the king of Baekje presented to him and Prince Opovake Buddhist books, and also sent a Buddhist teacher of percepts vinaya and meditation, master of Buddhist statues and builder of the Buddhist temples. They have lodged in a Buddhist temple of Prince Opovake in Naniwa (Nihon Shōki, V. II, 1973, pp. 110-111).

The resistance of Mononobe and Nakatomi to Buddhism becomes more clear, if to consider the position of the clan they belonged. At that time, all the aristocratic clans in Japan were divided into three categories: shimbetsu 神別, kōbetsu 皇別 and bambetsu 万別. Shimbetsu were considered to derive from Shinto gods kami 神. Kobetsu were the descendants of emperors who ruled after the legendary emperor Jimmu. And, finally, bambetsu belonged to the clans of immigrants from Korea and China. Clan Mononobe belonged to shimbetsu, the most influential aristocratic branch and were loyal to the Shinto holy traditions. The opposite to Mononobe clan was the Soga family, who derived from kōbetsu and thus stood slightly lower in social terms. For this reason, Soga made every effort to strengthen their influence at court. With the help of marriages, initiating the Regency Institute of sekkan, they interacted with the imperial family (Tamura, 1980, p. 62). Therefore the clan representatives, however, understood that the full realization of their ambitions is not possible within the existing system of clan aristocracy. They sought to establish a similar system of governance, which was adopted in China and Korea, a system which has transformed the barbaric country Yamato into the civilized State. Therefore, Soga patronized immigrants from China and Korea, and showed interest to news from the continent. For example, the record in Nihon Shōki states that in 555 and 556 years, Soga-no Iname led the settlement of Korean immigrants from Koguryō and Baekje in provinces Yamato and Bizen (Nihon Shōki, V. II, 1973, p. 84).

As the result of all this, it is not surprising that Soga-no Iname advocated Buddhism, in which he saw a new religion, giving the endless opportunities for people regardless of their origin.

In these conditions, a history of the formation of the first Buddhist Sangha in Japanin VI c. A.D. could serve as an example of the unique history of interaction between Buddhism and Japanese autochthonous religion Shinto. The first Buddhist Sangha in Japan, at the same time, was also a female Buddhist community of nuns in this country. This fact marks Japan in the history of Buddhism, because in the other countries of South, South-East Asia and the Far East the Buddhist sangha of monks and nuns was formed almost simultaneously, as the nuns could receive a dedication only from the tutor, in the presence of adequate number of monks and nuns. The peculiarity of the image of Buddhist nuns in early medieval Japanese sources is obvious in comparison with the descriptions of Tibetan yoginis and Chinese Buddhist nuns. 


\section{The Description of Japanese Buddhist Nuns in Historical and Buddhist Sources}

The first Japanese nuns (尼 $a m a$ ) mentioned in the Japanese sources of VIII c. Nihon Shōki 日本書紀 “The Annals of Japan”, “Gangōji Garan Engi Narabi ni Ruki Shizaichō” (元興寺伽藍縁起并流記資財帳, Origins of the Gangōji Monastery and Its Assets), and "Nihon ryōiki" 日本霊異記 "Miraculous Stories from the Japanese Buddhist Tradition", were descendants from the families of Chinese-Korean migrants. It could be assumed that the choice of the women, designed to embody the Dharma in Japan, was not accidental and was driven by the perception of the Buddha image at the time of its introduction in Japan in VI century.

Many researchers point out that the original Buddha could be perceived by the Japanese by their polytheistic beliefs as the deity, endowed with all the abilities of the Shinto deities. In the Nihon shōki, Gangōji Engi and Nihon ryoiki, there are such epithets of the Buddha as the "overseas God" (他國神 adashikuni-no kami), "God-Buddha" (仏神 hotoke gami), etc.. Perhaps the reason why the nuns were the original base of the Buddhist Sangha in Japan, was that they should serve to the new deity Buddha, similar as the Shinto priestesses.

In the "Annals of Japan", their appearance is the result of the Minister (oōmi) Soga-no Umako's desire to practice the cult of Buddha. Soga-no Umako 蘇我馬子 was the son of Soga-no Iname and inherited his father's devotion to Buddhism. In the record of 584 is said: “In the same year, Soga Umako-no sukune 蘇我馬 子宿襧 asked to find two of the Buddha images 佛像 (bukkyō zo) and sent Shiba Datito 司馬達等, the headman of the harness makers village 鞍部村主 (kuratsukuri-no sukuri) and Hita-atae from Ikebe, in four parts of the country to look for the proper Buddhist monk. Only in Harima province they found a person returning from the monkhood in the world 僧還俗者 (hōshikaeri-no mono). His name was Hye Phyōn (Jp. Eben) 惠便 of Koguryō (Jp. Koma) 高麗. Oomi 大臣 (Soga-no Umako) then ordered to him to become a Buddhist teacher once more. He converted in the Buddhist faith Sima, the daughter of Shiba Dachito. She was called nun Zenshin 善信, her age was eleven years old 年十一歳 (toshi jüichi sai) ${ }^{1}$. In addition, oomi ordered to convert into the nuns two other girls. One was Toyome, the daughter of a Han (Chinese) man (漢人 ayabito) called Yabo; her name is nun Zendō 禪藏. The second was Ishime, daughter of Nishikori-no Tsuu 錦織壹, called nun Ezen 惠善” (Nihon Shōki, V. II, 1973, pp. 112-113).

From this passage, it is evidently, that the first nuns were descendants from the families of immigrants from China (Sima and Toyōme) and Korean Baekje (Ishime). This fact could be considered as an evidence, that Buddhism in Japan began to spreading in the circles of the continent immigrants, who already known this religion. The Korean and Chinese immigrants often brought with them a new technology of crafts, building technology, agriculture and so on, therefore, the Japanese emperors and local aristocracy needed craftsmen from continent, and, sometimes, specially invited them. As the chronicles Fusō ryakki and Nihon Shōki reports the Chinese harness makers, led by Shiba Dachito, settled in Takechi region, at south of Naniwa. Later, at the second half of VI century, there settled harness makers, arrived from Baekje. Takechi region was placed near the territories, belonged to Soga clan, and while the political influence of Soga increased, the more kuratsukuri clans become dependent upon this family. Due to Soga's patronage, the leaders of Korean kuratsukuri become the most influential persons between immigrants in VI century (Lewin, 1962, p. 64).

In Gangoji engi... is also mentioned a certain old nun (Sn. bhikšuni, Jp. bikuini 比丘尼), named Hōmei 法明, who, along with Hye Phyōn, was the Buddhist teacher of first nuns (Gangoji garan engi, 1975, p. 87). In

${ }^{1}$ In Gangoji engi is told, that she was seventeen years old. (Gangoji garan engi, 1975, p. 87 ) 
comparison with Nihon shōki, the position of nuns seems to be more active. In Gangoji engi, Shima, Toyome and Ishime become the disciples of Hōmei voluntarily and openly declare their wish to become Buddhist nuns. Further is stated that the Soga settled nuns in the temple of Buddha Maitreya (Miroku 彌勒), build near the gate of his house, to carry on Buddhist rites Hoe and Imi (經營佛殿於宅東方安置爾勒石像屈請三尼大會設 斎。Shikerite butsu-no den ni oite taku no hōkata ni masemashiru Miroku no ishizo wa imasete mitsu ama wa daie no wakamisu) (Nihon Shōki, V. II, 1973, pp. 112-113). Imi (or misu) 斉 was the cleansing fast, prohibited to kill living creatures and eating the meat of animals. Hoe 法会 was called a meeting of Buddhist monks, who read and interpreted the sutras, discussing dogmas. However, it is doubtful that, in this period, Japanese nuns had enough knowledge to hold similar meetings. Probably, on my opinion, the nuns carried on some other Buddhist rituals and, consider the young age of the Zenshin and the fact that her deep knowledge in Buddhism is not mentioned anywhere, it is unlikely that Zendo and Ezen could be her disciples. Most likely, it could be the above-mentioned Hye Phyōn or nun Hōmei, mentioned in Gangoji Engi.

This hypothesis seems plausible, especially there is little information about the first nuns in Nihon Shōki, and, oddly enough, almost no mention of their merit in spreading Buddhism in Japan. This fact seems astonishing, especially when compared with the hagiographies of Tibetan yoginis Machig Labdrön and Yeshe Tsogyal) and Chinese nuns ("Biquini Zhuan") of IV-VII centuries.

\section{Tibetan Yoginis and Chinese Nuns}

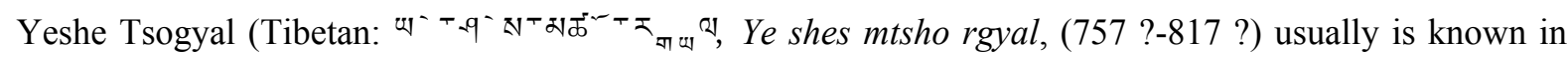
the Nyingma tradition of Tibetan Buddhism as the Great Bliss Queen. She is also considered as female deity called a Dakini. According to her biography, she was the wife of Emperor Trisong Detsen (740-c. 798) who invited Guru Padmasambhava to Tibet. As the wife of Tri-song-day-tsen and the consort of Padmasambhava, given to him at her request by the king, she also stands historically at the beginning of Buddhism's spreading in Tibet. She is also considered a manifestation of goddess Sarasvati and sometimes identified with the female Bodhisattva Tara.

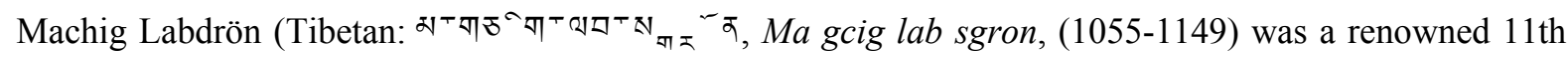
century Tibetan tantric Buddhist practitioner, teacher and yogini who originated several Tibetan lineages of the Vajrayana practice of Chöd.

Here's the description of the different Tibetan yoginis:

(1) They all are reincarnations of the Dakinis and possess supernatural abilities (siddhi), i.e. the ability to instantly understand the complex doctrines; could leave the prints of their arms and legs in the stone; walk in the air; quickly travel for a long distances; stay for a long time without food or water, eating substances, minerals and plants Dakinis and bodhisattvas frequently appears before Tibetan yoginis in the process of teaching and spreading the Dharma. Supernatural features are also reflected in their appearance (J. Simmer-Brown, 2002, pp. 194-199). It is known that Machig Labdrön was born with three eyes, one of which was located in the middle of the forehead, and Yeshe Tzogyal used the Tantric meditation to control the "five elements" of her body and due to this practice was not susceptible to aging and disease. The most characteristic feature of all Tibetan yoginis, are the signs of the sacred Sanskrit letters "A", "Aum", "Hum", on their bodies, described as the manifestation of the Dakini nature, distinguishing yoginis from ordinary people (J. 
Simmer-Brown, 2002, pp. 189-194).

(2) Yoginis are actively involved in the dissemination of Buddhism in Tibet and other neighbor countries. For example, Yeshe Tsogyal, a Tantric consort of famous Tibetan guru Padmasambhava, was directly involved in the disputes between the Buddhist monks and bon-magicians at the Court of the Tibetan Emperor Trisong Detsen and along with Padmasambhava had sought the recognition of Buddhism as the official religion of Tibet. She was said to spread tantra in Tibet and Nepal, and the number of her disciples, according to her hagiography, was more than 1,000 (Keith Dowmen, 1984, pp. 70-85). Machig Labdrön (1055-1145), considered as a reincarnation of Yeshe Tsogyal, was the founder of the new yogic practice Chod, a method, "cutting off" affections by forgetting fear. The aim of this method was the breaking all ties with samsara and included visits to graveyards or places regarded as defiled, as the offering of the one's one body to the ghosts and demons, living in cemeteries, as many other practices (J. Simmer-Brown, 2002, pp. 189-202). In the process of spreading the Dharma yoginis also subdue the local deities and demons, using their magical power siddhi. Usually, they transform local deities to bodhisattvas guarding the holy places. For example, Yeshe Tsogyal during her meditation in the cave Nehring Senge Zong by the force of her samadhi subdued the demons and deterrent deities of Tibet and convinced them to become the guardians of the Buddha's teachings (Keith Dowmen, 1984, pp. 65-68).

(3) All of the most significant events in the life of the yoginis (taking the Buddhist vows, preaching the Dharma, participating in debates, meeting with Lama, etc.) are accompanied by defining supernatural signs: the emergence of rainbow lights, heavenly music, flower rain, etc. The same phenomena, including the emergence of dakinis, deities, the sound of mantras, accompany the birth of yoginis and their passing away. During the death of Yeshe Tsogyal the countless dakinis in different hypostasis, demons and local deities, converted by Tsogyal to Buddhism, had appeared, according to her hagiography. Four heavenly kings went down from heavens to accompany her to the country of dakinis. When Yeshe Tsogyal said her farewell to her disciples, her body dissolved into bright light and disappeared (Keith Dowmen, 1984, pp. 155-161).

The hagiographies of Chinese Buddhist nuns of Six Dynasties. Biquini Zhuan 比丘尼傳 from the fourth to the early sixth century, compiled by the monk Baochang between 516 and 519, their images are painted in the same colorful manner. Comparing the stories of Tibetan yoginis with "Biquini Zhuan", one could notice similar features. For example, many Chinese nuns, as well as a Yoginis, from the very childhood stand out with their desire to study the Dharma and their extraordinary abilities. In the story of the two young nuns-sisters Fayuan and Fachai, they were miraculously transferred to the pure land of the Buddha Amida and took monastic ordain there. After returning to the human world, they have gained the ability to read and interpret the sutras in Sanskrit (Georgieva, 2000, p. 111).

The author of Biquini Zhuan frequently mention about nuns deep wisdom, eloquence and ability to interpret Dharma, contributing to the spread of Buddhism in China. Nun Ang Lingshou (IV c.) became famous as a famous teacher of Dharma, which had more than 200 disciples. She also founded the five monasteries and was esteemed by the Emperor Shi Hu (333-334). Nun Daochin (376-438), famous for her eloquence, during the reign of Emperor Xiaowu (376-397) was invited to the palace to read sutras specifically for the wives and concubines of the Imperial harem. Nun Myaoin, who was the Abbess of the nunnery in the capital, also had great influence at this emperor and took part in philosophical disputes and literary contests (Georgieva, 2000, p. $113,189)$.

As many Tibetan yoginis, Chinese Buddhist nuns gained supernatural powers through meditation and 
strict asceticism. In many cases, it is evident, as the ability of the nuns to contemplate the Buddha's pure land of Amida, various Buddhas and bodhisattvas, speak other languages, read and interpret the sutras, etc. In some cases, the demonstration of supernatural abilities of the nuns had received its recognition at the highest level. For example, nun Daolun had the ability to neutralize the evil charms and omens. She held an exorcism ritual in the Palace of Emperor Tsyan Weng (371-372) and thereby contributed to his conversion to Buddhism. Nun Tsintsyan healed the Crown Prince and for this reason was deeply respected by Emperor Wen (r. 424-453) of the Song dynasty (Georgieva, 2000, pp. 168-169).

The hallmark of the Chinese nuns was their asceticism and aversion to the flesh, sometimes taking a rigorous form. In Biquini Zhuan, is also mentioned about self-burning of some nuns, as the highest form of offerings to the Three Jewels that was uncharacteristic of early Indian Buddhism and its other forms.

The role of female Buddhist Sangha in the history of the spread of Buddhism in South-East Asia and the Far East still provokes a discussion between the buddologists and orientalists. The history of Japan's first Buddhist Sangha, which had a female structure, at first glance, looks as the chronicler's attempt to emphasize the merit of oomi Soga-no Umako, introducing the Buddhist nuns as obedient performers of his will. However, this is not entirely true.

\section{The Image of Japanese Buddhist Nuns, As the Divine Priestesses of God-Buddha}

In the Nihon shōki and Gangoji Engi as well as in Tibetan and Chinese sources, are mentioned the persecutions of Buddhism by the followers of Shinto. A plauge epidemic broke out in the country (疫疾流行 iyami amaneku okote) and, seizing this opportunity, the Ministers Mononobe 物部 and Nakatomi 中臣 announced that the reason of this misfortunes was a new deity Buddha, worshiped by Soga-no Umako (豈非專 由蘇我臣之興行佛法歟 Ani hi takume ni yoru ni Soga-no oomi kore kōgyō ni hotoke no hō wo ya). Mononobe by command of the Emperor, ordered to burn the Buddha Temple and his statue, and throw the ash in Naniwa channel. He also ordered to his subordinate official Mimuro to punish nuns, who were defrocked, imprisoned and flogged. Obviously, the act of punishment, when the officials took away the three nuns monastic clothes (有司便奪尼等三衣 Shikasa tsuide ni ubatte ama nado no san e) was sought to deprive the nuns of their holy status and return them to the position they occupied as laywomen. Minister Soga, however, convinced the emperor to allow him to worship the Buddha and return the nuns at his house (Nihon Shōki, V. II, 1973, p. 114).

This event is remarkable that it was the first mention in sources where nuns showed personal initiative. In 588, according to Nihon Shōki, the nun Zenshin and other nuns also asked Soga-no Umako to send them to Baekje 百濟 to study the Buddhist percepts (學受戒法 gaku jukaihō): “The nun Zenshin and others told to oomi: The way of Buddhist monk (出家之途 Ihede no kono michi) consists in the observance of [Buddhist] percepts (戒筄本 imashime wo nasu moto) (Nihon Shōki, V. II, 1973, P. 125).”

As Gangoji engi explains, the main reason was the absence in Japan, the proper quantity of the Buddhist monks and nuns, who could perform official ordination. As an ambassador from Baekje, told Soga-no Umako: "In order the nuns could pass the ordination, in a nunnery must be ten nuns. And in the monastery should be ten monks. These twenty monks and nuns must pass the ordination. But in your country there is only nunnery (尼 寺 amadera) and no monastery with the monks (法師寺 hōshidera) there. So if the nuns could be ordained in accordance with the regulations, you should build a monastery and to invite monks and nuns of Baekje (Kudara)”. (尼等受戒法者尼寺之法 先請十尼師 受本戒已 即詣法師寺請十法師. 先尼師十合廿師 
所受本戒也. 然此國者 但有尼寺 無法師寺及僧. 尼等若爲如法者 設法師寺 請百濟國之僧尼等 可令受戒白. Ama nado ga jukai no hō wa,amaderano naka ni mazu jūnishi wo masete sude ni honkai wo uke, sunawachi hōshidera ni itari jūhōshi wo masu. Saki no nishijū to awasete nijüshi ga tokoro ni honkai ga ukeru nari. Shikaru ni kita no kuni wa tada amadera narite, hoshidera oyobi zō nashi. Amadera, moshi hō no gotoku shisan to seba, hōshidera wo mouke, Kudara kuni no sōni nada wo koite, jukai seshimu beshi.) (Gangoji garan engi, 1975, p. 89).

It is noteworthy that in Gangoji Engi, Soga Umako is depicted not as powerful minister, but rather as a layman-homeowner, sustaining the Sangha. In the text, he is often referred "Umako" as a simple official. This could be explained as, first, by the Buddhist implication of the compilers of Gangoji Engi, highlighting first the servants of Buddha, and, secondly, to emphasize the role of Empress Suiko and Prince Shōtoku — the official founders of Gangoji temple - in the spreding of Buddhism in Japan. After their return from Baekje, nuns had initiated the buildings of Buddhist temples in Japan. As Gangoji engi tells: "The nuns said: 'Build the hall to worship Buddha as soon as possible! (禮佛定忽作賜 Hotoke wo iyamau miya wo sumiyaka ni tsukuritamae) And also build the monastery to spent ceremonies (白羯磨 byakukatsuma) there!'. (Gangoji garan engi, 1975, p. 90).

As Gangoji Engi informs, the Empress Suiko, heeding the persuasion of nuns, ordered to rebuild her own Palace Toyura 豊浦 into the nunnery and bestowed to it the land, fields, ponds, homesteading and slaves (Gangoji garan engi, 1975, p. 91). The record in Nihon Shoki states that in the same year, when the nuns returned from Baekje, another 11 people took ordain. Two were the wife and daughter of the nobleman Otomo Sadehiko 大伴狭手彦, the remaining eight were descendants from China (漢人 ayabito) (Nihon Shōki, V. II, 1973, P. 125).

Discussing the story about the first nuns ordination in Baekje, an appropriate question arises: In what Vinaya (Buddhist percepts) tradition they took monastic vows? In text of Gangoji engi, the nuns tells, that in 588, they took ordination of six percepts (六法戒 rokuhōkai) and in the next year, 589, took full ordination (大戒 daikai). The six percepts meant the following six vows for nuns during ordination ceremony: rejecting worldly desires, not stealing, not eating meat, not drinking wine, not cursing and not taking food at a time disagreed. The full ordination was accompanied by promises to take 348 vows for women and 250 for men. It is evident, that in Baekje, the first Japanese nuns received full monastic vows for women, but still it's unclear to which Vinaya tradition they belonged.

As Ann Heirman (2011) points out, while more vinaya traditions have existed, the texts of six traditionsare extant, one in Pāli-the Theravāda tradition, and five in a Chinese translation. The first four of these have been translated in the fifth century. In chronological order these are the Shisong lu 十誦律, Sarvāstivādavinaya; the Sifen lu 四分律, Dharmaguptakavinaya; the Mohesengqi lu 摩訶僧祇律, Mahāsāmghikavinaya; and the Mishasai bu hexi wufen lu 彌沙塞部和醢五分律, Mahiśáasakavinaya. Later, in the beginning of the eighth century, the monk Yijing 義淨 translated large parts of the Mūlasarvāstivāda-vinaya (Genbenshuoyiqieyou bu pinaiye 根本說一切有部毘奈耶), as well as other vinaya texts belonging to the same school. Of the Mülasarvāstivāda-vinaya, a Tibetantranslation and many Sanskrit fragments are extant. Not all of the extant vinaya texts, however, are still actively used in full ordination ceremonies. Only three traditions have been continued: the Dharmaguptaka tradition mainly followed in China, Taiwan, Vietnam and Korea, the Mūlasarvāstivāda tradition based in Tibet, and the Southeast Asian Pāli Theravāda tradition. For nuns, the situation is different, since only in the Dharmaguptaka tradition, is a full ordination as a nun still possible (A. 
Heirman, 2011, p. 604).

Regarding this fact, it could be possible, that in Korean Baekje, first Japanese nuns could took monastic vows in the Dharmaguptaka Vinaya tradition, but there are no clear evidences in sources, because monastic Vinaya tradition (it was also Dharmaguptaka) spread in Japan only in VIII century.

In the text of Gangoji Engi, is also mentioned that Empress Suiko secretly took monastic vows under the name of novice Zenki, although it is not directly connected with the return of nuns from Baekje.

Having a number of similarities (persecutions by the anti-Buddhist, desire to receive more extensive and deep knowledge of Dharma) the information about the first Japanese nuns still differ considerably from the biographies of yoginis and Chinese Buddhist nuns. Even in the Buddhist chronicle Gangoji Engi, are no specific descriptions of the manifestations of Buddhas and bodhisattvas to the future nuns to show them a worldly impermanence, no references to their extraordinary abilities, appeared in a continuous meditations and reading the sutras, no mentions of them preaching the Dharma. It could be explained by the fact that Buddhism in Japan, since its inception has been inextricably linked with the authority system. Therefore, in the chronicles were highlighted the rulers (Empress Suiko and Prince Shōtoku) and officials (Soga-no Umako), whose sustain for the adoption of Buddhism contributed to the prosperity of the country. Accordingly, the role of the first Japanese nuns, no matter how sincere was their desire to practice Buddhism, inevitably was of secondary importance. However, if to think about how, in fact, could be perceived the image of Buddha at the first stages of the spreading of Buddhism in Japan, the activity of nuns could be seen in a different light.

In Gangoji Engi, is mentioned that the main occupation of the first Japanese nuns was making offerings (供 飬 kuyō, Sn.pujana) and prayers (禮帱 raihai, or iyamaiogamiki) to stone statue (石像 ishi zō) of Buddha Maitreya (Miroku 彌勒), brought in 584 from Baekje (Gangoji garan engi, 1975, p. 87). First, it was given to Soga-no Umako, but later, he placed it in the Sakurai Temple 櫻井寺. Even after their return from Baekje, the nuns didn't engage in the spreading of Dharma in Japan, as it could be expected, and continued to live in the Sakurai Temple. Their further role still was limited by the participation in Buddhist ceremonies, therefore, Sakurai temple was a special hall for Buddhist worship.

All of this has little in common with the hagiographies of Tibetan yoginis and Chinese Buddhist nuns, whose desire to give salvation to all sentient beings is, in the opinion of the authors of their live stories, the main sign of their true essence of a bodhisattva. The description of first Japanese nuns, whose activity consisted in the worship of the statue of Buddha, rather reminds the responsibilities of the Shinto priestesses whose role as the intermediates between people and gods included ritual ceremonies to appease the gods and contribute to the prosperity of the country.

This hypothesis seems plausible by the fact that during the early spread of Buddhism in Japan, Buddhas and bodhisattvas were worshiped, as well as indigenous Japanese deities-Kami. In the annals, Buddhist deities were called: “overseas gods" (他國神 adashikuni-no kami) and, in the view of Mark Teeuven, originally in the minds of Japanese people, Buddha was equated with Shinto Kami (Teeuwen M. \& Rambelli F., 2003, p.7).

In Nihon Shoki, Buddha is represented rather not as an embodiment of the essence of his teachings, manifesting his true appearance to faithful disciples (what is typical for Buddhist literature), but as the deity, that could send calamities and curses, having functions similar to the Shinto kami. Nihon Shöki tells us that during the persecution of Buddhism, in clear weather fell down the rain and stormy wind (是日無雲風雨 Kono hi ni nakute kumo kaze ni ame) (Nihon Shōki, V. II, 1973, p. 24), while Gangoji engi... adds, that the divine fire (神火 
shinka), suddenly began in Imperial Palace (終大宮神火出燒 Tsui ni oōmiya nishinka idete yakaretari), and the plague (疫疾 iyami) raged in the country (Gangoji garan engi, 1975, p. 85).

In Gangoji engi, is also pointed out, that all these calamities made emperor Yomei (r. 585-587) to become frightened by “the awful (恐物 kashikoki mono) God-Buddha (佛神 hotoke-gami) (Gangoji garan engi, 1975, p. 85)".

As the Shinto deity, Buddha in the description of the Nihon shōki is also capable to bring people harm or misfortune. In 585, when Soga-no Umako fell ill, he asked a fortuneteller-urabe 卜者, who determined the cause of his disease as a curse from the heart of a new God-Buddha (佛神之心也 hotoke kami-no mikokoro ninari), who was worshipped by his father-Soga-no Iname 蘇我稻目. When Soga-no Umako send a report about this event to emperor Bidatsu, the emperor ordered Soga to "worship the God of your father (祭祠父神 Ihahi mashiru kazo no kami wo)", according to the words of a fortune-teller about Buddha. As Nihon shōki tells, then minister Soga worshipped the stone image of Buddha and requested the extension of life.(大臣奉詔禮拜 石像. 乞延壽命. Oomi tatematsurite shō wo raihai shite ishi no zō wo. Koi wo eto jumyō.) (Nihon Shōki, V. II, 1973, p. 24).

It should be clear that this passage tells not about the bad qualities of a new deity Buddha. The word "[the curse of] god's heart (神御心 kami-no mikokoro)" is typical for Shinto sources. In Shinto religion, the gods-kami were not the embodiment of ethics and morals in the Christian sense of the word. By hurting people, thus kami made a sign about its existence or its will (order to erect a sanctuary, to appoint a specific individual priest, bring suitable gifts, etc.).

For example, in Kōjiki (古事記 “Records of Ancient Matters” or “An Account of Ancient Matters”, VIII c.), the oldest Japanese chronicle and collection of Shinto myths, are frequently mentioned the stories, when epidemics, calamities and other misfortunes were the results of the curse of kami. Thus, during the reign of the 10th emperor Sujin 崇神 (148 BC-29 BC), regarded as the founder of Yamato Dynasty, various illnesses (疫 病 eyami) spread through the country. The emperor was sad by this fact, and while he tried to ask the gods one night, he saw in a dream a Shinto god Ohomononushi-no kami (大物主大神), who told him, that the reason of the epidemic was his heart (是は我が御心ぞ Ko wa waga ga mikokoro zo). But if the emperor made the following prayers to this god, he would send the peace and prosperity to the country (Köjiki, 1958, p. 179).

The other story from Köjiki tells about the prince Homuchiwake-no miko, who was the son of the emperor Sunin 垂仁. This prince was dumb from his birth, and only after fortune-telling rites it became clear, that he was cursed (崇 tatari) by the heart (御心 mikokoro) of the great God-Izumo (出雲大神 Izumo-no oogami). Only after the emperor sent a prince to worship this god, his son healed and began to speak (Köjiki, 1958, p. 197).

In Gangoji engi, the main reason of the Mononobe and Nakatomi opposition to Buddhism was their argument, that introduction of a new religion could incense the native gods-kami: "Because we awe the wrath from the hearts of our gods (我等國神御心恐故 Watashitachi wa kunigami no mikokoro wo osoreru ga yue ni), we shouldn't worship the overseas gods. (他國神不可禮帱 Adashikuni no kami wa uyamaiorogamu bekarazu.)" (Gangoji garan engi, 1975, p. 83).

When in 571 a plague epidemic raged in the country, ministers Mononobe and Nakatomi declared that it was the wrath of kami's hearts, because Soga-no Iname committed sacrilege (罪 tsumi), worshiping the overseas God-Buddha (Gangoji garan engi, 1975, p. 83).

One of the main responsibilities of the Shinto priestesses was their intermediary role between the gods and 
humans, to whom they declared the divine will. Usually they communicated with the gods through playing musical instruments, because in ancient Japan it was believed that music and singing belongs to the Otherworld.

Although in Nihon Shōki and Gangoji Engi are no direct mentions of the similar features of Buddhist nuns, but the fact that Soga-no Umako and Empress Suiko unconditionally complied their request to send the nuns to Paekche and build Buddhist nunnery and monastery for ordination, suggests that the desire of nuns could be interpreted as the will of the deity Buddha, expressed by their mouths.

The attitude to the Buddhist nun, as the divine Priest of the deity-Buddha continued even later, in the Nara period. In Nihon ryoiki - a collection of Buddhist legends and traditions, compiled at the beginning of IX century by a Buddhist monk Kyōkai from the Yakushiji Temple, is contained the story of a Buddhist nun from the province of Kawachi 河內國, who led the local community and taught the Buddha's Dharma (知識 chishiki). She lived in a mountain temple in Heguri. In gratitude for the four kinds of benefits ${ }^{2}$, she drew the holy image [of Buddha] (尊像 sonzō). After [the ceremony] of offerings (供養 kuyō), it was set in a local Buddhist temple. One day, when the nun was absent, at this time the image was stolen. Later, when she, along with other nuns, went to the Naniwa for performing Buddhist rite of releasing animals (放生 hōjō), they saw hanging in a tree a merchant's basket from which the voices of living beings have been heard. The nuns wanted to redeem them from the owner, opened the basket and found the stolen image [of Buddha]. They become immensely happy. (Nihon Ryōiki, sc. 1-35, 1974, p. 72).

Therefore, in Nihon ryōiki, the nun, who created the image of Buddha, was at the same time its worshipper and the guardian. The text says that after the loss of the image, the nun "continued to preach Dharma (停知識 keichishiki)". One of the meanings of term 知識 chishiki is a Buddhist word, meaning "a leader, who guide towards the learning of Dharma". This implies that in the eyes of the community, she was both a priestess of Buddha and a preacher of Dharma. It is noteworthy, that indicating a nun as a Buddhist preacher, Kyōkai, the author of Nihon Ryöiki didn't mention her knowledge of sutras, or the way she preached Dharma. Rather, he depicted various Buddhist ceremonies that she and other nuns spent in local temple. When the Buddha image miraculously returned to the nun, along with the other nuns, she started to conduct in the temple memorial services (修福 shufuku) and rites of releasing animals (放生 hōjō) (Nihon Ryōiki, sc. 1-35, 1974, p. 72). During this ceremonies, the term 供養 kuyō (Sn. pujana), “making offerings" draws attention, because the same one is mentioned in Gangoji engi, meaning the holy obligations of the first Japanese nuns. It should be noted, that the rite of releasing animals (放生 hojjō) also was connected with kuyō and usually spent after this ceremony of offerings. These Buddhist ceremonies were widely spread in Japan during Nara period in VII and VIII centuries. This fact means, that in the eyes of the author of Nihon Ryoiki, the nun from Kawachi province was, first of all, a priestess, who created the sacred image of Buddha (尊像 sonzō) and spent various Buddhist religious ceremonies in local temple.

\section{Conclusion}

Accordingly, based on the comparison of the legends about the first Japanese Buddhist nuns with hagiographies of Tibetan Yoginis and Chinese nuns, we could make the following conclusions. The spreading of Buddhism in Japan had a qualitative gender peculiarity (forming the first Buddhist Sangha of nuns, and not of the monks), which was contrary to the Buddhist traditions and the requirements of Vinaya, and was not

${ }^{2}$ Four kinds of benefits (四恩 shion)—the Buddhist conception of benefits, made for us by parents, king, all living beings, and Three Treasures (Buddha, Dharma and Sangha). 
marked in any other country of the Buddhist area. This peculiarity could be explained by the existing differences within the Japanese aristocracy, which had different grades of sacredness and the desire to use Buddhist teachings as a magical tool in the struggle for power in accordance with the existing Shinto religious practices. Therefore, the status of Buddhist nuns was equal to the position of Shinto priestesses, although Buddhism at this stage was regarded as a foreign religion, but having the same magical power as Shinto.

\section{References}

Dowman, K. S (1984). Dancer: The secret life and songs of the Lady Yeshe Tsogyel. Boston: Routledge \& Kegan Paul. Georgieva, V. (2000). Buddhist nuns in China: From six dynasties to Tang. Leiden: Universiteit Leiden.

Heirman, A. (2011). Buddhist nuns: Between past and present. Numen: International Review for the History of Religions, 58, 603-631.

Kurano, K., \& Yūkichi, T. (1958) Kōjiki shukushi (Records of Ancient Matters) \& Nihon koten bungaku taikei (The collection of Japanese classical literature). Tokyo: Iwanami Shōten.

Lewin, B. (1962). Aya und Hata: Bevölkerungsgruppen altjapans kontinentaler herkunft. Wiesbaden: Harrassowitz..

Kyōkai. (1974). Nihon ryōiki (Miraculous Stories from the Japanese Buddhist Tradition) // Nihon koten bungaku taikei (The collection of Japanese classical literature), V. 70. Endo Yoshimoto, (Ed.). Tokyo: Iwanami Shōten.

Kuroita, K. (1973). Nihon Shōki (Annals of Japan )// Kokushi taikei (Series on national history), V. II. Tokyo: Yoshikawa Kōbunkan.

Sakurai, T. (1975). Gangojigaranengi. Jishaengi (The records about the foundation of Gangoji temple and its treasures) // Nihon shisotaikei (Series on the Japanese philosophical thought), V. XX. Tokyo: Iwanami Shōten.

Simmer, B. J. (2002). Dakini's warm breath. The feminine principle in Tibetan Buddhism. Boston \& London: Shambhala.

Tamura, E. (1980). Kodai Chōsen bukkyōtoNihonbukkyō (The ancient Korean and Japanese Buddhism). Tokyo: Yoshikawa Kōbunkan.

Teeuwen, M., \& Rambelli, F. (2003). Buddhas and Kami in Japan: Honji Suijaku as a combinatory paradigm. London: Rutledge Curson. 